\title{
Chromium (III) and chromium (VI) as important players in the induction of genotoxicity - current view
}

\author{
Ewa Sawicka ${ }^{1, A-D \oplus}$, Karolina Jurkowska ${ }^{1, C-D \oplus}{ }^{\text {, Agnieszka Piwowar }}{ }^{1, A, D-F \oplus}$ \\ ${ }^{1}$ Medical University, Wrocław, Poland \\ A - Research concept and design, B - Collection and/or assembly of data, C - Data analysis and interpretation, \\ $D$ - Writing the article, E-Critical revision of the article, F- Final approval of article
}

Sawicka E, Jurkowska K, Piwowar A. Chromium (III) and chromium (VI) as important players in the induction of genotoxicity - current view. Ann Agric Environ Med. 2021; 28(1): 1-10. doi: 10.26444/aaem/118228

\begin{abstract}
Introduction. Genotoxicity of chemical compounds is primarily associated with the interaction with DNA, formation of mutations, damage to chromosomes and initiating carcinogenesis processes. Currently, many compounds found in the environment are considered to be genotoxic agents, among them chromium: trivalent (III) and hexavalent (VI). The genotoxicity of hexavalent (VI) chromium has been proven in numerous epidemiological, in vitro and in vivo studies. The main source of $\mathrm{Cr}(\mathrm{VI})$ is environmental pollution associated with its use in various industries. On the other hand, the role of chromium (III) as a microelement is widely discussed. Due to its beneficial properties, associated with maintaining adequate blood glucose levels and supporting weight loss, it is widely used in the form of dietary supplements, often in doses exceeding the daily requirement. However, the safety of chromium compounds is disputable. Data about the mechanism of genotoxic effects are still incomplete.

Objective. The aim of this review is to present the current knowledge about the induction of genotoxicity from two forms of chromium: trivalent (III) and hexavalent (VI).

State of knowledge. Chromium (VI) is a carcinogen with proven mutagenic and genotoxic effects, but this issue is still being investigated by scientists. In recent years, numerous studies have also been conducted on the genotoxic effect of chromium (III).

Conclusions. Due to the still unexplained mechanism of the genotoxic action and incomplete knowledge about the transformation of chromium in the body, further research is needed, especially due to the growing popularity of Cr (III) compounds and their consumption in the form of dietary supplements and doubts as to the safety of its use, as well as environmental exposure to $\mathrm{Cr}(\mathrm{VI})$.
\end{abstract}

\section{Key words}

chromium (III), hexavalent, trivalent, chromium (VI), toxicity, genotoxicity, dietary supplements

\section{INTRODUCTION}

The genotoxicity of different chemicals is generally identified with respect to DNA or chromosomal damage and its fixation. This damage can be manifested in different ways, e.g. as a form of gene mutation, structural chromosomal aberration, recombination and numerical changes. These changes are responsible for heritable effects on germ cells and pose risks to future generations. In addition, it is documented that somatic mutations can also play an important role in mutagenesis and carcinogenesis. Different chemicals have the potential to be human carcinogens and/or mutagens $[1,2]$. Cancer diseases are one of the main problems of modern society and an ongoing serious medicinal problem worldwide. The morbidity and mortality they cause are constantly increasing, as a result, among others, by the ever-growing number of different factors (xenobiotics) present in the environment that promote genotoxic changes and process of carcinogenesis [3]. Among them, a large group with such properties includes metal ions, one of them being chromium compounds, which are the major inorganic environmental pollutants connected

Address for correspondence: Karolina Jurkowska, Medical University, Wrocław, Poland

E-mail: k.jurkowska93@o2.pl

Received: 02.09.2019; Accepted: 16.02.2020; First published: 10.03.2020 with occupational exposure. These ions are released into the environment through various natural and anthropogenic activities and exist mainly in two forms: trivalent [Cr (III)] and hexavalent [Cr (VI)]. Hexavalent chromium compounds are extensively applied in diverse industries, while trivalent chromium salts are used as micronutrients and dietary supplements $[4,5]$.

Chromium ions can be absorbed by the organism in three ways: orally, percutaneously, or through inhalation, but the efficiency of absorption depends mainly on the oxidation grade of these compounds - chromium (VI) is much more effectively absorbed than its trivalent form, which can be associated with its genotoxic effect $[6,7]$. Under physiological conditions, it is not possible to oxidise the trivalent form of chromium to hexavalent, whereas the inverse process of reducing $\mathrm{Cr}$ (VI) to $\mathrm{Cr}$ (III) normally occurs in organism cells. As a result of this process, many chromium intermediates can be generated, such as chromium (V) and chromium (IV), as well as reactive oxygen species (ROS) which damage cell biomolecules. These naturally-occurring oxidation states of chromium differ significantly in their mobility and toxicity. $\mathrm{Cr}$ (III) and Cr (VI) are the most stable oxidation states of chromium present in the environment $[4,7]$.

The description of properties, sources of origin, action and influence of chromium compounds on the human body has 
been the subject of numerous studies [8, 9, 10]; therefore, this issue will not be discussed in this review. However, there are relatively fewer studies on the genotoxic effects of the compounds of chromium, especially its trivalent form.

\section{OBJECTIVE}

The aim of this review is to present the current view and knowledge concerning the two best known forms of chromium - chromium (III) and chromium (VI), and their role in the induction of genotoxic changes in the human body. It is especially important from the point of view of the growing popularity of $\mathrm{Cr}$ (III) as an essential trace element in human and animal nutritional supplements, and the presence of $\mathrm{Cr}$ (VI) in components of industry chemicals and environmental pollution. Their role as genotoxic agents is discussed especially from the aspects of increasing doubts about the safety of chromium (III). In recent years, a lot of research, including in vitro, in vivo and epidemiological studies, has been conducted to evaluate the carcinogenicity induced by $\mathrm{Cr}$ (VI) and $\mathrm{Cr}$ (III) compounds.

The presented review is based on literature research using the PubMed and Google Scholar databases and includes recent data which were published from 2000 onwards, mostly in English, with the use of the following search terms or their combinations: chromium compounds, chromium (III), chromium (VI), toxicity, genotoxicity, DNA damage, chromium supplements, environmental exposure. This review included research on human and some animal and cell models. Finally, 88 items from original papers and reviews were selected, which seemed to be the most useful and fitting in relation to this issue.

\section{STATE OF KNOWLEDGE}

Chromium toxicity. High levels of exposure to Cr (VI) are present in chromate manufacturing, chrome plating, ferrochrome production and stainless-steel welding. Occupational exposure to $\mathrm{Cr}$ (VI) compounds is the cause of respiratory cancers, and $\mathrm{Cr}(\mathrm{VI})$ is a proven toxin, mutagen and carcinogen. $\mathrm{Cr}$ (VI) is considered to be more toxic than $\mathrm{Cr}$ (III) due to its high solubility and mobility. The hexavalent form is mainly used in industry and in 1990 it was recognised by the International Agency for Research on Cancer (IARC) as a carcinogen with a proven carcinogenic effect on humans (class I). It is a known carcinogen absorbed through inhalation and associated with lung, nasal, and sinus cancers $[11,12]$. Numerous critical reviews have evaluated the exposure to toxic and carcinogenic hexavalent chromium from a number of pathways, including workplace air, cement and packaging materials [13]. Many types of structural genetic lesions induced by $\mathrm{Cr}$ (VI) have been observed in vivo and in vitro, including inter-strand cross-links, DNA protein crosslinks, strand breaks and the creation of Cr-DNA adducts. Association with the phosphodiester backbone of DNA (chromium-DNA adduct) is one of the most abundant genetic lesions induced by chromium in mammalian cells and is thought to be a primary cause of Cr (VI) mutagenicity [14].

Recently, the importance of chromium to the human body raises more and more controversy due not only to the known toxic and pro-carcinogenic effects of its hexavalent form, but also the adverse effects of trivalent compounds revealed in recent years. Lastly, the status of Cr (III) as an essential micronutrient for humans is under question; yet, an increase in the number of purchased products containing chromium is currently observed $[5,15]$. For years, chromium in the trivalent form has been recommended as a trace element necessary for the proper functioning of the organism. It is present in food in the form of an organic and inorganic mixture and is widely used in dietary supplements [16, 17]. Nearly 60 years ago, chromium, as a trivalent ion, was proposed to be an essential element, but the results of recent studies indicate that at present chromium can only be considered pharmacologically active and not an essential element [18]. Chromium (III), as an insulin-mimetic agent, is often present in the form of nutritional supplements, such as chromium (III) picolinate $\left[\mathrm{Cr}(\mathrm{pic})_{3}\right]$ or chromium chloride. Although the use of large doses of Cr (III) supplements may lead to improvements in glucose metabolism in type 2 diabetes, there is a growing concern over the possible genotoxicity of these compounds, particularly of $\mathrm{Cr}(\mathrm{pic})_{3}$. A possible way of action of Cr (III) is indicated: (i) presence of partial hydrolysis products of Cr (III) nutritional supplements, which are capable of binding to biological macromolecules and altering their functions; and (ii) highly reactive $\mathrm{Cr}(\mathrm{VI} / \mathrm{V} /$ IV) species and organic radicals, formed in reactions of $\mathrm{Cr}$ (III) with biological oxidants. Naturally-occurring oxidation states differ significantly in their mobility, bioavailability and toxicity $[6,19]$.

Considering the fact that chromium supplements are currently the second most often sold in the market of vitamin and mineral supplements in the United States, and that a growing trend of buying preparations containing chromium compounds is also observed in Poland, the problem of its genotoxicity is current and important [5, 20]. Attention should be paid to the possibility of adverse reactions associated with the use of compounds containing chromium (III). In general, chromium (III) supplementation is considered safe for humans; however, high dietary doses of Cr (III) can probably limit the absorption of iron and zinc ions, as well as affect calcium metabolism in bones [21, 22 . The results of studies on animals indicate a potentially beneficial effect of chromium (III), e.g. on the prevention of diabetic microvascular complications in kidneys or on the prevention of atherosclerosis and heart disease, on glycaemic normalization, or as weight loss supplements [5, 23, 24, 25]. However, other data do not support these results $[21,26,27]$. $\mathrm{Cr}$ (III), as a metalloestrogen, is associated not only with interaction with DNA through estrogen receptors but also through the induction of oxidative stress (OS) associated with the excessive production of ROS $[27,28,29,30]$.

The molecular mechanism of chromium (III) carcinogenicity is still unclear and data in this respect are incomplete. Evaluation of the genotoxic effect of trivalent chromium requires further research, particularly regarding the estimation of its content in food [31, 32, 33]. Assessing the genotoxic risk of trivalent chromium as an essential trace element and a widely-used human and animal nutritional supplement is especially important. Reports of the induction of genetic damage in cultured cells exposed to $\mathrm{Cr}$ (III) compounds in vitro have heightened concerns that $\mathrm{Cr}$ (III) compounds may exert genotoxic effects under certain conditions, raising the question of the relative risk-benefit ratio of dietary and feed supplementation practices $[34,35]$. In 
vitro data show that $\mathrm{Cr}$ (III) can potentially react with DNA and cause DNA damage in cell culture systems. This will be described in detail in the section concerning the genotoxicity of chromium (III) compounds.

Genotoxicity. The pathological impact of the action of genotoxic compounds is distant toxic effects, which become evident after an indefinite latent time. Xenobiotics causing such changes in the organism are known as genotoxic, and the result of their action as genotoxicity. The activity of these compounds may concern not only the host organism on which a biologically-active substance acts but also their offspring [36]. All compounds that have the ability to bind DNA in cells, affecting its structure and function, and DNA repair systems are considered genotoxic. Their action then leads to mutations and permanent changes in the genetic material, including, for example, changes in the structure and number of chromosomes or in the transformation of cells. Such modifications can be divided into four groups depending on the changes that they trigger. These are: modification of one base, change of two bases, breaking the DNA chain and cross-linking. These modifications can affect somatic or reproductive cells [37]. Xenobiotics can react with DNA directly or indirectly. The majority of indirect damage is attributed to the production of ROS and, simultaneously, it is a faster way of their genotoxic action. Being especially reactive, hydroxyl radicals are examples. On the other hand, direct action may be caused by radiation, exogenous alkylating agents or aromatic amines, which can react with genetic material in cells $[38,39]$.

There are many methods to assess genotoxicity. A number of tests to assess genotoxicity have been developed in recent decades. The basic criterion for distributing tests is the type of parameter being tested. Genotoxicity tests include the study of gene mutations, e.g. a primary mutation test in Salmonella typhimurium or gene mutation testing in mammalian cells in vitro. In addition, chromosomal aberrations are studied, e.g. in vivo cytogenetic bone marrow testing in mammals (chromosome analysis), a micronucleus test or a dominant lethal mutation test. Apart from this, the effect of OS action on DNA, e.g. 8-oxy-2'-deoxyguanosine (8-oxy-dG) and its tautomeric form - 8-hydroxy-2'-deoxyguanosine (8-OHdG), may be examined $[40,41,42]$.

It seems that the most commonly used methods in scientific studies include the examination of DNA damage through visible genotoxic action. One of them is the single-cell gel electrophoresis (SCGE), also known as the comet assay. This name stems from the image obtained by electrophoresis and observed under a fluorescence microscope, which resembles a comet in shape. A correlation between the content of DNA in the comet's "tail" and the amount of DNA damage caused by xenobiotics has been demonstrated $[43,44]$. The comet assay enables the detection of single-strand breaks, double-strand breaks, chemical modifications (occurrence of apolar sites or unstable adducts), as well as enzymatic DNA changes (oxidative damage), depending on the conditions of performing the experiment [43]. Holton at al. [45] described an innovative method called Repair Assisted Damage Detection (RADD), which is able to detect DNA nuclear changes in cells as well as damage in various species and types of tissues. DNA repair enzymes that are used in this method can be adjusted depending on the DNA changes tested, and the labelled nucleotide can also be selected depending on the desired reading. The RADD method provides high-content screening capable of monitoring a wide spectrum of DNA damage without the need for DNA isolation.

Some authors indicate that DNA deletions (DEL assay) occurring as a result of intrachromosomal homologous recombination are a useful endpoint for studying chromium genotoxicity [46]. Additionally, monitoring chromium toxicity and remediation processes - combining a whole-cell bioreporter and Cr isotope techniques - can be applied [47], as well as the use of a whole-cell bioreporter, Acinetobacter baylyi, to estimate the genotoxicity and bioavailability of chromium (VI)-contaminated soils [48]. To identify Cr (VI) reduction pathways, metal-mineral-microbe interactions and stable isotope fractionation factors can be applied [49]. A detailed literature review of the genotoxicity of chromium (VI) will be discussed below.

Genotoxicity of various chromium compounds. Increasingly more attention is paid to the fact that the toxic and mutagenic action of chromium refers not only to the element at higher oxidation levels, i.e., Cr (VI), Cr (V), but also to Cr (III) and probably $\mathrm{Cr}$ (II). Information about the carcinogenic effect of chromium (III) as well as data on its genotoxic potential have also been revealed in recent years. Evidence is growing that metabolites of $\mathrm{Cr}$ (III) dietary supplements are partially oxidised to carcinogenic $\mathrm{Cr}$ (VI) and $\mathrm{Cr}(\mathrm{V})$ in vivo [50]. Stearns et al. [51] reported that samples of $\mathrm{CrPic}$ tested in an acetone suspension were mutagenic and clastogenic to Chinese hamster ovary (CHO)-AA8 cells, and the coordination of $\mathrm{Cr}^{3+}$ with picolinic acid may be more genotoxic than other $\mathrm{Cr}^{3+}$ forms. The ability of $\mathrm{Cr}(\mathrm{pic})_{3}$ to form free peroxide radicals appears to be due to the presence of an aromatic bidentate ligand in the structure. For chromium complexes with amino acids (arginine, aspartic acid, glycine, hydroxyproline and lysine), such as glycinate and propionate, mutagenic properties have not been confirmed [52, 53, 54].

In industry, it is possible for employees to contact chromium compounds, in which it occurs at various levels of oxidation. Metallic and chromium (II) do not occur under physiological conditions in the environment, are very unstable and quickly oxidise to chromium (III) compounds, which are the most durable form of this element. Chrome in the form of chromates (VI) and dichromates (VI) was considered to be carcinogenic and mutagenic [55]. Wakeman et al. [56] demonstrated that MLH1 repair protein (human mutL homolog 1) with DNA mismatch is required for DNA damage caused by indirect tetravalent chromium. In addition, chromium gets into water resources and, as a result, into the food chain. It has been confirmed that hexavalent chromium compounds that can be found in the diet can cause gastrointestinal cancer. They can also interact directly with the DNA of gastric mucosa cells, obtained by gastroscopy, as confirmed by alkaline gel electrophoresis in a single cell [57]. Supplies of drinking water in many geographic areas also contain chromium (III) and (VI). The unfavourable action of $\mathrm{Cr}$ (VI) is well documented, it has high environmental mobility and can come from anthropogenic and natural sources. Acidic environments with a high content of organic substances favour the reduction of $\mathrm{Cr}$ (VI) to non-toxic $\mathrm{Cr}$ (III). There is also the reverse process of formation of $\mathrm{Cr}$ (VI) from Cr (III), especially in the presence of common minerals containing manganese oxide (Mn (IV) oxides: birnessite, cryptomelane, todorokite and hausmannite) [58]. 
The Cr (III) cytotoxicity depends on the coordinated ligand, its concentration and time of exposure. For example, the complexes of $\mathrm{Cr}$ (III) with histidine or oxalate as ligands are not carcinogenic, but such properties are indicated for the three-core Cr (III) complex with an acetate anion and a complex with a picolinate anion, which are associated with high-concentration chromium as well as with the presence of ascorbate and hydrogen peroxide $[30,59]$.

Genotoxicity of chromium (III). In the scientific literature, there are increasing doubts about the safety of consuming particularly high doses of Cr (III) supplements, especially those containing $\mathrm{Cr}(\mathrm{pic})_{3}[34,60]$. $\mathrm{Cr}$ (III) compounds are considered about 100 times less toxic than Cr (VI) [61]. Chromium (III) used to be considered non-toxic, but it was found that it is capable of generating hydroxyl radicals. Its toxicity has recently been demonstrated by decreasing the plasma's ability to reduce iron ions or to induce lipid peroxidation. In addition, $\mathrm{Cr}$ (III) has a well-documented ability to bind DNA [62]. These features are associated with a lower penetration of Cr (III) by biofilms because unlike $\mathrm{Cr}$ (VI), which is an anion and is transported by anion transporters - Cr (III) does not have such properties. Although Cr (III) complexes cannot penetrate cell membranes easily, they have the ability to accumulate around cells to induce morphological changes on the cell surface and cause damage to cell membrane lipids by disrupting the function and integrity of the cell, ultimately causing DNA damage [63]. According to the IARC, trivalent chromium has no carcinogenic effect on the human organism, thus it is classified under group 3. Although chromium (III) is not considered a direct carcinogen, it plays a major role in chromium (VI)-induced chromogenesis, which results from "chain" reduction reactions on $\mathrm{Cr}$ (II) occurring in the cell nucleus $[64,65]$.

Available in vivo evidence suggests that genotoxic effects are unlikely to occur in humans or animals using Cr (III) supplementation in proper doses. However, an excessive consumption of $\mathrm{Cr}$ (III) supplements does not seem justified at present. The potential for genotoxic side-effects of $\mathrm{Cr}$ (III) complexes may outweigh their possible benefits as insulin enhancers, and the recommendations for their use as either nutritional supplements or antidiabetic drugs need to be reconsidered in the light of some studies and should ultimately be limited $[34,63,66]$.

The genotoxicity of $\mathrm{Cr}$ (III) is indirectly connected with the reduction of $\mathrm{Cr}(\mathrm{VI})$ inside cells to trivalent chromium, which displays an affinity for both DNA bases and the phosphate backbone. A diverse array of genetic lesions is produced by $\mathrm{Cr}$ including Cr-DNA monoadducts, DNA inter-strand crosslinks (ICLs), DNA-Cr-protein cross-links (DPCs), apurinic/ apyrimidinic site (also known as an abasic site), DNA strand breaks and oxidised bases [67]. Cr (III), the product of $\mathrm{Cr}$ (VI) reduction, forms six bonds that enable intermolecular cross-linking. The ability of Cr (VI) to cause ICLs, whose formation mechanisms and presence in human cells are still uncertain, was studied. Morse et al. [68] suggest that the generation of ICLs by chromate is probably an in vitro phenomenon occurring under conditions permitting the formation of $\mathrm{Cr}$ (III) oligomers. The authors found that the in vitro reduction of $\mathrm{Cr}$ (VI) with glutathione showed a sublinear production of ICLs, the yield of which was less than $1 \%$ of total Cr-DNA adducts under optimal conditions. They additionally indicated inhibitory effects of ligand-Cr (III) binding on the formation of cross-linking species. Cr (III), considered a non-toxic form of chromium, has the ability to form complexes with DNA and takes part in the induction of oxidative stress and generating hydroxyl radicals, which can be a potential mutagenic factor [62]. The ability of chromium (III) to form Cr (III)-DNA complexes and cross-links through the interaction of $\mathrm{Cr}$ (III)-DNA complexes with glutathione, histidine or cysteine, the adducts of which have a mutagenic effect, was demonstrated. Cr (III)-DNA and histidine-Cr(III)DNA adducts induce the passage of nitrogenous bases: $G$ : C $\rightarrow$ A: T (where G - guanine, C - cysteine, A - adenine and $\mathrm{T}$ - thymine) and the transversion of nitrogenous bases: $\mathrm{G}$ : $\mathrm{C} \rightarrow \mathrm{T}$ : A with a similar frequency, while the glutathione$\mathrm{Cr}$ (III)-DNA adduct is mainly responsible for $\mathrm{G}: \mathrm{C} \rightarrow \mathrm{T}: \mathrm{A}$, $\mathrm{G}: \mathrm{C} \rightarrow \mathrm{T}: \mathrm{A}$ transversion. Both changes in the structure of DNA promote the formation of mutations in cells, inhibition of replication, consequently leading to programmed cell death, i.e. apoptosis [69].

Figgitt et al. [70] investigated whether Cr (III), Cr (VI), Co (II) and their interactions can induce chromosomal aberrations in human fibroblasts in vitro. They used the same concentrations found in the peripheral blood of exposed people (in industry, the environment, and after replacement surgery of the CoCr alloy in the implant) using 24-colour M-FISH, which is a sensitive way to detect translocations and aneuploidy, and they examined the effects of a 24-hour exposure and its impact up to 30 days after exposure to record genomic instability and/or repair. As representing levels of these metals found in the blood of patients with worn implants, higher physiological doses: 20 and $25 \mathrm{ppb}$ or 40 and $50 \mathrm{ppb}$ (parts per billion) were applied respectively. The metals were examined individually and in combination to investigate a potential synergy between cobalt and chromium. The authors showed that physiological doses of these metal ions mainly induced numerical aberrations rather than structural aberrations. In addition, they revealed that Co was the least reactive, while $\mathrm{Cr}$ (VI), especially in combination with Co, was the most reactive. All metals ions at the highest physiological doses (40 and $50 \mathrm{ppb}$ ) caused simple (a gain or loss of three or fewer chromosomes) and complex (over 49 chromosomes) aneuploidy. In addition, both metal ions at the lowest physiological dose caused a significant increase in total aberrations. The authors concluded that these metal ions can cause chromosomal aberrations in peripheral blood lymphocytes at the above doses [70].

El-Yamani et al. [71] examined chromium compounds (hexavalent sodium chromate and trivalent chromium chloride) in human lymphoblastoid line cells (TK6). Both compounds were genotoxic using the comet assay, although the percentage of tail DNA obtained after treatment with $\mathrm{Cr}$ (VI) was significantly higher than that obtained for $\mathrm{Cr}$ (III) at higher tested concentrations: $0.8 \mathrm{mM}$ and $1 \mathrm{mM}$. Further, treatment with formamidopyrimidine (FPG) and endonuclease III (EndoIII) showed a greater degree of DNA damage, indicating that the induction of oxidised bases is a significant part of the damage caused by chromium compounds. In addition, kinetic repair studies have shown that the generated DNA damage is removed after about eight hours, with the damage caused by $\mathrm{Cr}$ (III) repairing faster than the damage caused by $\mathrm{Cr}$ (VI). These data indicate that a large proportion of chromium-induced DNA damage is correlated with oxidative damage and that both $\mathrm{Cr}$ 
compounds interfere with the repair mechanisms involved in the repair of DNA damage caused by gamma radiation [71].

The Novotnik group [72] recently pointed to the possibility of the formation of chromium chelates with EDTA (ethylenediaminetetraacetate) at high concentrations in surface waters as common environmental pollutants. Their presence can lead to the occurrence of $\mathrm{Cr}$ chelation with EDTA, thus a stable Cr (III)-EDTA complex was formed. The cytotoxic and genotoxic activity of Cr (III)-EDTA was evaluated in comparison to the activity of $\mathrm{Cr}$ (VI) and $\mathrm{Cr}$ (III) nitrate in a human haepatoma cell line (HepG2) at cytotoxic $(0.04 \mu \mathrm{g} / \mathrm{mL}-25 \mu \mathrm{g} / \mathrm{mL}$ after 24 -hour exposure) and noncytotoxic concentrations. The authors revealed that $\mathrm{Cr}$ (VI) at concentrations $\geq 0.2 \mu \mathrm{g} / \mathrm{mL}$ and $\mathrm{Cr}$ (III) at $\geq 1.0 \mu \mathrm{g} / \mathrm{mL}$ resulted in DNA damage, whereas after exposure to $\mathrm{Cr}$ (III)EDTA no crack was determined in the DNA strand. This is evidence that Cr (III)-EDTA does not induce DNA damage and does not affect the genomic stability of HepG2 line cells, it should therefore not pose an environmental or health problem.

Fang et al. [14] compared the effect of $\mathrm{Cr}$ (VI) (i.e. $\mathrm{CrO}_{3}$ ) and $\mathrm{Cr}$ (III) (i.e. $\mathrm{CrCl}_{3}$ ) on DNA damage both in vivo and in vitro. They conducted studies in cell-free systems and demonstrated that $\mathrm{Cr}$ (III) does bind to DNA, leading to a decrease in the fidelity and an increase in the processivity of DNA polymerases, which may ultimately lead to increased mutations. The authors found that the compounds increase the rate of mutation and cause DNA degradation and showed that both forms can induce genetic mutations in yeast cells. Surprisingly, they observed that $\mathrm{CrCl}_{3}$ is more genotoxic than $\mathrm{CrO}_{3}$ in both yeast and animal cells. Additionally, it was found that these two compounds interact with DNA differently. $\mathrm{CrO}_{3}$ binds to DNA in an intercalative manner and irreversibly destroys the DNA configuration. In contrast, $\mathrm{CrCl}_{3}$ interferes with the base pairing mode. These results suggest that both trivalent and hexavalent chromium compounds are genotoxic and cause DNA damage, but the ability of $\mathrm{CrCl}_{3}$ to generate DNA damage is significantly greater than that of $\mathrm{CrO}_{3}$ However, it remains unclear whether $\mathrm{Cr}$ (III) and $\mathrm{Cr}$ (VI) act on DNA through the same or different mechanisms [14].

The studies carried out by the National Toxicology Program (NTP) [73] revealed that during the standard screening assays conducted by the NTP, Cr(pic) ${ }_{3}$ monohydrate showed no clear evidence of genotoxicity. It was not mutagenic in the majority of genotoxicity tests used: Salmonella typhimurium strains TA98 or TA100 or Escherichia coli strain WP2 uvrA/ pKM101. No increase in the frequency of micronucleated normochromatic erythrocytes (MNEs) was observed in male B6C3F1 mice fed with $\mathrm{Cr}$ (pic) ${ }_{3}$ monohydrate for three months. Additional genotoxicity testing was conducted using $\mathrm{Cr}(\mathrm{pic})_{3}$ (not the monohydrate form of the compound) - the results were also negative. No induction of gene mutations after $\mathrm{Cr}$ (pic) ${ }_{3}$ was observed in two independent studies conducted in several strains of $S$. typhimurium. On the basis of these two-year feed studies, there was equivocal evidence of the carcinogenic activity of chromium picolinate monohydrate in male $\mathrm{F} 344 / \mathrm{N}$ rats given an increase in the incidence of preputial gland adenoma. There was no evidence of the carcinogenic activity of chromium picolinate monohydrate in female $\mathrm{F} 344 / \mathrm{N}$ rats or in male or female B6C3F1 mice [73]. Estimating the genotoxicity of chromium (III) propionate complex in rat's peripheral blood lymphocytes by the comet assay, the team of Staniek et al. [74] carried out research on eighteen 12-week-old female Wistar rats, which was supplemented by $\mathrm{Cr}$ (III) and $\mathrm{Cr}$ (VI) in different combinations (but equivalent to $100 \mathrm{mg} \mathrm{Cr} / \mathrm{kg}$ body mass/ day, for four weeks) in the daily diet. The authors found that high doses of supplementary $\mathrm{Cr}$ (III) did not affect body mass gain, feeding efficiency ratio or internal organ masses. Treating rats with the Cr (III) propionate complex, in contrast to $\mathrm{Cr}$ (VI), did not affect the comet assay results in lymphocytes significantly, which suggests that the compound does not exert genotoxic effects in rats [74].

Ateeq et al. [75] revealed that occupational exposure to trivalent chromium can lead to oxidative stress and DNA damage in tannery workers. They showed that blood chromium, DNA damage, superoxide dismutase (SOD) and malondialdehyde (MDA) levels were significantly higher, while the glutathione (GSH) level was significantly lower in workers (exposed group) compared to the control group. Correlation analysis demonstrated a significant relationship between the blood chromium level with oxidative stress parameters and DNA damage. The results of the comet assay showed that the mean tail length of the exposed group was significantly higher compared to the control. The authors underline that the chromium concentration in erythrocytes is a sensitive indicator of a recent exposure to Cr. Furthermore, lymphocytes, due to their relatively long life span (ranging from several months to years), are indicated as good chromium exposure markers. They are also capable of great uptake, intracellular reduction and accumulation of chromium (VI). Their chromium content represents the amount accumulated over a long period of time and more accurately may express the blood cell body burden. The authors concluded that DNA damage and the blood chromium level may serve as an efficient biomarker in tannery workers exposed to trivalent chromium [75].

Genotoxicity of chromium (VI). As already mentioned, Cr (VI) is classified under group 1 of human carcinogenic agents by IARC (International Agency for Research on Cancer) because there is sufficient evidence of the carcinogenicity of these compounds in humans. In addition, the European Union (EU), Environmental Protection Agency (EPA) and World Health Organization (WHO) included chromium (VI) compounds as carcinogenic to humans. Chromium (VI) compounds in in vitro and in vivo studies caused: damage to DNA, mutation of genes, increased frequency of sister chromatid exchange and chromosome aberrations [76, 77].

Most of $\mathrm{Cr}$ (VI) compounds in the EU are classified under category $1 \mathrm{~B}$ according to the CLP classification (classification, labeling and packaging) due to the initiation of the process of carcinogenesis in animals. CLP is a EU regulation from 200, which aligns the EU system of classification, labelling and packaging of chemical substances and mixtures to the Globally Harmonised System (GHS). Classification and labelling identify hazardous chemicals and inform users about their hazards through standard symbols and phrases. The most important substances containing hexavalent chromium can include: chromium (VI) oxide, chromate (VI), dichromate (VI) and chromium dioxide dichloride, commonly known as chromic chloride [13]. Chromium (VI) oxide, chromate (VI) and nickel (II) dichromate and zinc chromates (VI) are marked with the 1A symbol, which refers to a carcinogenic substance detected on the basis of 
epidemiological studies. Chromium (VI) compounds in the form of alkali metal salts and ammonium salts, as well as chromium trioxide with chromyl chloride, are classified under category $1 \mathrm{~B}$ due to mutagenic effects on reproductive system cells [78].

Chromium (VI) is a recognised human carcinogen, can get into the cells with the anionic sulfate/phosphate transport system, and can then be reduced to lower-valency semiproducts consisting of pentavalent chromium, tetravalent chromium or $\mathrm{Cr}$ (III) by cell reducers [63]. Hexavalent chromium is associated with occupational lung cancer and poses a significant public health concern. When exposed to $\mathrm{Cr}(\mathrm{VI})$, cells rapidly internalise this compound and metabolise it to $\mathrm{Cr}$ (III). By-products of $\mathrm{Cr}$ (VI) metabolism include unstable $\mathrm{Cr}(\mathrm{V})$ and $\mathrm{Cr}$ (IV) intermediates that are believed to be directly responsible for the genotoxicity and carcinogenicity caused by $\mathrm{Cr}$ (VI) exposure. However, the carcinogenic potential of the Cr intermediates and the mechanisms of Cr-induced carcinogenesis remain to be further defined [79]. Wakeman et al. [56], utilising synthetic $\mathrm{Cr}$ (IV) and $\mathrm{Cr}(\mathrm{V})$ compounds, demonstrated that exposure to both compounds induces DNA double-strand breaks; however, of the two compounds, mammalian cells only respond to $\mathrm{Cr}(\mathrm{V})$-induced DNA damage.

Strong oxidation-reduction properties of chromium (VI) are indicated as a basis of its toxicity. The genotoxicity of $\mathrm{Cr}$ (VI) is rather caused by the products of its downregulating metabolism. Semi-finished products - ROS and $\mathrm{Cr}[(\mathrm{Cr}(\mathrm{V})$ and $\mathrm{Cr}(\mathrm{IV})]$ - are potential sources of oxidative damage induced by $\mathrm{Cr}$ (VI) [80]. Cr (VI) does not interact directly with DNA and thus its genotoxicity is attributed to its intracellular reduction to $\mathrm{Cr}$ (III) via reactive intermediates. The resulting DNA damage can be divided into two categories: (i) oxidative damage to DNA and (ii) Cr (III)-DNA interactions [46]. In general, literature data provide evidence for a three-step cross-linking mechanism involving: (i) reduction of $\mathrm{Cr}$ (VI) to $\mathrm{Cr}$ (III), (ii) $\mathrm{Cr}$ (III)-DNA binding, and (iii) protein capture by DNA-bound Cr (III) generating protein-Cr (III)-DNA cross-links. It is known that hexavalent chromium is an inducer of the creation of DNA-protein cross-links that contributes by the repression of inducible genes and the genotoxicity of this metal, whereas lymphocytic DPCs have also shown potential usefulness as biomarkers of human exposure to $\mathrm{Cr}$ (VI). In vitro reactions of $\mathrm{Cr}(\mathrm{VI})$ with one-electron reducing thiols (glutathione and cysteine) or two-electron donating ascorbate were all efficient in DPC production, indicating a dispensable role of $\mathrm{Cr}(\mathrm{V})$ [81]. Cr (VI) transforms with the participation of cytochrome P450, as well as vitamin B5 and glutathione with a genotoxic superoxide or hydroxyl radicals, as well as hydrogen peroxide production. The first reduction stage is the reaction of chromium (VI) with glutathione, resulting in a thiol radical of glutathione that reacts with other compounds containing the thiol group, resulting in the formation of a superoxide anion radical. Both the primary substrate $-\mathrm{Cr}$ (VI) - and the final product - Cr (III) - take part in the Fenton reaction, contributing to the formation of hydroxyl radicals, and $\mathrm{Cr}(\mathrm{VI})$ also catalyses the formation of superoxide anion radicals with $\mathrm{H}_{2} \mathrm{O}_{2}[46,69]$. O'Brien et al. [82] revealed that hypoxia hinders the formation of chromium DNA adducts. They found that although hypoxia lasting two hours does not inhibit the reduction of $\mathrm{Cr}$ (VI) by ascorbic acid, the binding of Cr-DNA under these conditions was reduced to $70 \%$ by hypoxia. Previously, Quievryn et al. [83] showed that in human fibroblasts the reduction of carcinogenic $\mathrm{Cr}$ (VI) by vitamin $\mathrm{C}$ at a physiological concentration, produces cross-links of ascorbate-Cr (III)-DNA, binary adducts of $\mathrm{Cr}$ (III)-DNA, and can potentially cause DNA oxidative damage through intermediate reaction products. It turned out that the crosslinks of Cr (III)-DNA ascorbate were significantly more mutagenic than the smaller Cr (III)-DNA adducts and accounted for over $90 \%$ of $\mathrm{Cr}$ (VI) mutagenicity. Ternary adducts were also several times stronger in inhibiting replication than binary complexes.

In the study on the WTHBF- 6 cell line (human lung cells), evaluating the effect of $\mathrm{Cr}(\mathrm{VI})$ on DNA damage and using the comet assay, it was shown that the exposure of cells to zinc chromate (II) and sodium chromate (VI) significantly increases double-strand breaks of the DNA strand, compared to cells not exposed to such compounds [84, 85]. However, in the study on A549 cell lines (human lung cancer cells) and BEAS-2B (human bronchial epithelial cells) using the comet assay, it was revealed that sodium chromate significantly increases the amount of DNA damage [86]. Cavallo et al. [85] found that $\mathrm{Cr}$ (VI) at concentrations of $0.5 \mathrm{M}, 1.0 \mathrm{M}, 1.0$ $\mu \mathrm{M}$ also caused DNA damage, but it was also demonstrated that in the case of $\mathrm{Cr}(\mathrm{VI})$ at concentrations of $0.5 \mu \mathrm{M}$ and $10 \mu \mathrm{M}$, the number of DNA breaks was dependent on the time of exposure to this xenobiotic.

The ability of $\mathrm{Cr}$ (VI) to induce inter-strand DNA crosslinks between chains (ICLs), whose mechanisms of formation and presence in human cells are not fully understood, was examined. Morse et al. [68] found that chromium (VI) cross-links DNA between chains in vitro, but does not show hypersensitivity in human cells lacking cross-link repair. They suggest that the generation of ICLs (cross-links between DNA chains) by chromate is probably an in vitro phenomenon under conditions that allow $\mathrm{Cr}$ (III) oligomers to be formed. Xie et al. [86] explored whether $\mathrm{Cr}$ (VI) particles induce double-strand breaks (DSB) in human bronchial cells, and showed that this major chemical carcinogen can induce both DNA double-strand breaks and alter their repair. Chromate, the predominant form of $\mathrm{Cr}(\mathrm{VI})$ at neutral $\mathrm{pH}$, is taken up by all cells through sulphate channels and is not enzymatically activated by ubiquitous ascorbate and small thiols. The most common form of DNA damage caused by $\mathrm{Cr}$ (VI) is Cr-DNA adducts that cause chromosomal mutations and cracks. Emerging evidence points to bidirectional interactions between DNA damage and epigenetic changes that collectively determine the spectrum of genomic rearrangements and gene expression profiles in tumours. The extensive formation of DNA adducts, pronounced positivity in genotoxicity tests with high predictive values for carcinogenicity, the shape of tumour-dose responses in mice, and a biological signature of mutagenic carcinogens (multispecies, multi-dependent and transgenic carcinogenesis) strongly support the importance of mutagenic mechanisms responsive to DNA in the carcinogenic activity of $\mathrm{Cr}(\mathrm{VI})$. The results of bioavailability and kinetic considerations suggest that $10-20 \%$ of a low dose of Cr (VI) consumed, escapes human gastric inactivation [58]. Recently, Krawic et al. [87] made an interesting observation concerning interactions between chromate - Cr (VI) - and three other metal ions [Fe (III), Mn (II), Ni (II)] that are typically released from stainless-steel welding particles. In human lung epithelial cells (with physiological levels of ascorbate and glutathione), 
the authors showed that $\mathrm{Cr}(\mathrm{VI})$ was by far the most cytotoxic metal in single exposures, but co-exposure with Fe (III) suppressed the cytotoxicity and genotoxicity of Cr (VI), which resulted from a severe inhibition of chromium uptake by cells and required extracellular ascorbate/glutathione. In chemical terms, the detoxification of Cr (VI) occurred via its rapid extracellular reduction by $\mathrm{Fe}$ (II) that primarily originated from ascorbate-reduced Fe (III). Glutathione was a significant contributor to the reduction of $\mathrm{Cr}$ (VI) by $\mathrm{Fe}$ only in the presence of ascorbate.

These findings established an important case when exposure to mixtures causes the inactivation of a potent human carcinogen. What is more, they showed that the variability in Cr (VI) metabolism among common cell culture media was caused by their different Fe content. Ni (II) and Mn (II) had no detectable effects on the metabolism, cellular uptake or cytotoxicity of Cr (VI). This was confirmed in three human lung cell lines, including stem cell-like and primary cells [87]. Gaddameedi et al. [66] examined the role of insulin in Cr (VI)-mediated genotoxicity. They applied a wall-less mutant of Neurospora crassa (FGSC Stock No. 4761), known to possess an insulin receptor in its cell membrane, and hence a good model for chromium toxicity research. The authors explored the toxicity of $\mathrm{Cr}$ (VI) and the possible impact on a simultaneous exposure to insulin in Neurospora crassa. The comet assay of $N$. crassa cells treated with 100 $\mu \mathrm{mol} \mathbb{1}^{1} \mathrm{Cr}(\mathrm{VI})$ showed up to a $50 \%$ reduction in comet tail lengths when incubated simultaneously with $0.4 \mathrm{U}$ insulin. The authors concluded that the insulin-mediated protection from DNA damage by $\mathrm{Cr}(\mathrm{VI})$ is the result of scavenging free radicals liberated during $\mathrm{Cr}$ (VI) exposure. In general, $\mathrm{Cr}$ (VI) toxicity is dependent on available insulin, showing that $\mathrm{Cr}$ (VI) toxicity can be a serious problem in people with diabetes who have insufficient insulin [66].

Table 1. Summary of genotoxic effects of $\mathrm{Cr}$ (III) and $\mathrm{Cr}$ (VI)

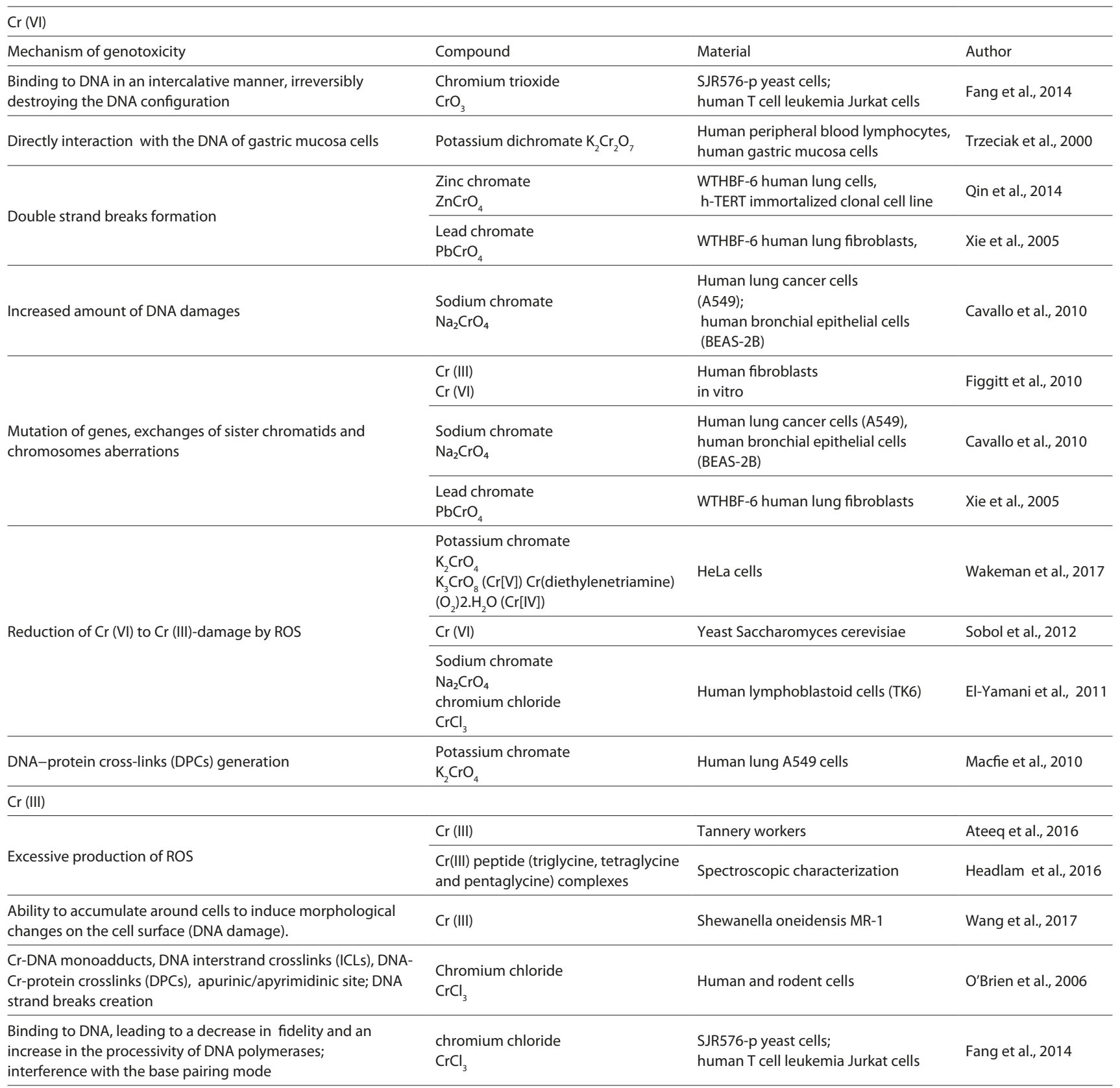


Estimation of the mutagenicity and genotoxicity of $\mathrm{Cr}(\mathrm{VI})$ in accordance with the National Toxicology Program (NTP) in male and female mice and rats revealed clear evidence of its carcinogenicity, and confirmed its mutagenicity in numerous in vitro assays, in animals (mice and rats) and in humans In addition to the association with the occurrence of respiratory cancers (lung, nasal, larynx, sinus cancers) and exposure to chromium compounds, some meta-analyzes provided data on the relationship between this exposure and the occurrence of other human cancers such as: stomach, brain, malignant lymphoma, myeloid leukemia, bladder and panreatic cancers [88].The studies postulated key steps in tumour formation, which included the interaction of DNA with Cr (VI) and reduction to Cr (III), mutagenesis, or cell proliferation. Within the timeframe and tumourigenic dose range for early events, genetic changes in mice (single/ double-stranded DNA breaks) commence within $24 \mathrm{~h}$. Mechanistic evidence was also found for oxidative damage and DNA adduct formation contributing to tumour response. Therefore, the weight of evidence supports the plausibility that $\mathrm{Cr}$ (VI) may act through a mutagenic mode of action [89]. Table 1 summarizes the genotoxic effects of Cr (III) and $\mathrm{Cr}(\mathrm{VI})$.

\section{CONCLUSIONS}

Human exposure to heavy metals has been reported and requires further research. Although some of these heavy metals are essential elements for humans, they may also be toxic at low concentrations due to various mechanisms of action. Genotoxic studies of both Cr (VI) and Cr (III) were reviewed based on the literature data. Evaluation of the genotoxicity of $\mathrm{Cr}(\mathrm{VI})$ - a chromium compound and mainly trivalent chromium, requires reconsideration, especially towards the estimation of $\mathrm{Cr}$ (III) action which is present at higher concentrations in food and dietary supplements. The literature data indicate that the safety of use of $\mathrm{Cr}$ (III) compounds has recently provoked controversy. Their use in dietary supplements is undetermined and an excessive intake of Cr (III) supplements does not appear to be justified at present. As with other agents of nutrients exhibiting genotoxic effects in vitro under high-exposure conditions, nutritional benefits thus appear to outweigh the theoretical risk of genotoxic effects in vivo only at normal or slightly elevated physiological intake levels.

Even though the mechanisms of Cr (VI) genotoxic action is known, the issue with $\mathrm{Cr}$ (III) is still under discussion and remains not clearly explained. It is evident that scientific papers on the genotoxicity of chromium (III) are very diverse, some of them being aware of the genotoxic effect of this metal ion, while others deny it. Thus, research on the genotoxic effects of chromium compounds, especially trivalent compounds, should be continued and their reasonable use should be recommended.

\section{Acknowledgements}

The review was prepared under the project the 'Regional Initiative of Excellence' programme for 2019-2022 (Project No. 016/RID/2018/19), financed by the Ministry of Science and Higher Education in Warsaw, Poland, The review was also supported by the Medical University in Wrocław, Poland (Grant No. ST-D150.18.004).

\section{REFERENCES}

1. Jena GB, Kaul CL, Ramarao P. Genotoxicity testing, a regulatory requirement for drug discovery and development: impact of ich guidelines. Indian J Pharmacol. 2002; 34: 86-99.

2. Phillips DH1, Arlt VM. Genotoxicity: damage to DNA and its consequences. EXS. 2009; 99: 87-110.

3. Mohamed S, Sabita U, Rajendra SV, Raman D. Genotoxicity: Mechanisms, Testing Guidelines and Methods. Glob J Pharmaceu Sci. 2017; 1(5). doi: 10.19080/GJPPS.2017.02.555575

4. Hamilton EM, Young SD, Bailey EH, Watts MJ. Chromium speciation in foodstuffs: A review. Food Chem. 2018; 250(1): 105-112. doi: 10.1016/j. foodchem.2018.01.016

5. Jurkowska K, Sawicka E, Piwowar A. Chrom - pierwiastek już dobrze znany czy wciąż nieznany - dwa oblicza działania. Farm Pol. 2019; 75(4): 208-218.

6. O'Flaherty EJ, Kerger BD, Hays SM, Paustenbach DJ. A physiologically based model for the ingestion of chromium(III) and chromium(VI) by humans. Toxicol Sci. 2001; 60(2): 196-213.

7. Jomova K, Valko M. Advances in metal-induced oxidative stress and human disease. Toxicology. 2007; 283(2-3): 65-87. doi: 10.1016/j. tox.2011.03.001

8. Surgiewicz J. Chrom i jego związki - metoda oznaczania. Podstawy i Metody Oceny Środowiska Pracy. 2009; 1(59): 113-118.

9. Lewicki S, Zdanowski R, Krzyżowska M, Lewicka A, Dębski B, Niemcewicz M, et al. The role of Chromium III in the organism and its possible use in diabetes and obesity treatment. Ann Agric Environ Med. 2014; 21(2): 331-335. doi: 10.5604/1232-1966.1108599

10. Piotrowska A, Pilch W, Tota $€$, Nowak G. Biological significance of chromium III for the human organism. Med Pr. 2018; 69(2): 211-23. DOI: $10.13075 / \mathrm{mp} .5893 .00625$

11. Mishra S, Bharagava RN. Toxic and genotoxic effects of hexavalent chromium in environment and its bioremediation strategies. J Environ Sci Health C Environ Carcinog Ecotoxicol Rev. 2016; 34(1): 1-32. doi: 0.1080/10590501.2015.1096883

12. IARC Working Group on the Evaluation of Carcinogenic Risks to Humans (2012): Chromium(VI) Compounds. In: Arsenic, metals, fibres, and dusts. IARC Monogrophs on the Evaluation of Carcinogenic Risks to Humans; 100(Pt C). International Agency for Research on Cancer (IARC), Lyon pp 147-167.

13. Skowroń J, Konieczko K. Związki chromu(VI) - w przeliczeniu na Cr(VI) Dokumentacja proponowanych dopuszczalnych wielkości narażenia zawodowego. Podstawy i Metody Oceny Środowiska Pracy 2016; 2(88): 15-112 DOI: 10.5604/1231868X.1205475

14. Fang Z, Zhao M, Zhen H, Chen L, Shi P, Huang Z. Genotoxicity of tri- and hexavalent chromium compounds in vivo and their modes of action on DNA damage in vitro. PLoS One. 2014; 9(8): e103194. doi: 10.1371/journal.pone.0103194

15. Levina A, Lay PA. Chemical properties and toxicity of chromium(III) nutritional supplements. Chem Res Toxicol. 2008; 21(3): 563-71. doi: $10.1021 /$ tx700385t

16. Sobański L, Sprzęczka-Niedolaz M, Łebek G. Rola chromu w życiu człowieka. Bromat Chem Toksykol. 2007; 2: 113-119.

17. Hernandez F, Bemrah N, Séby F, Noël L, Guérin T. Cr(VI) and Cr(III) in milk, dairy and cereal products and dietary exposure assessment. 2019; 1: 1-7. doi: 10.1080/19393210.2019.1598506

18. Vincent JB. New Evidence against Chromium as an Essential Trace Element. J Nutr. 2017; 147(12): 2212-2219. doi: 10.3945/jn.117.255901

19. Sugden K, Stearns D. The role of chromium(V) in the mechanism of chromate-induced oxidative DNA damage and cancer. J Environ Pathol Toxicol Oncol. 2000; 19: 215-230.

20. Kantor ED, Rehm CD, Du M, White E, Giovannucci, EL. Trends in Dietary Supplement Use Among US Adults From 1999-2012. JAMA. 2016; 316(14): 1464-1474. doi: 10.1001/jama.2016.14403

21. Lukaski HC, Siders WA, Penland JG. Chromium picolinate supplementation in women: effects on body weight, composition, and iron status. Nutrition. 2007; 23(3): 187-95. doi: 10.1016/j.nut.2006.12.001

22. Lewicki S, Zdanowski R, Krzyżowska M, Lewicka A, Dębski B, Niemcewicz M, et al. The role of Chromium III in the organism and its possible use in diabetes and obesity treatment. Ann Agric Environ Med. 2014; 21(2): 331-5. doi: 10.5604/1232-1966.1108599

23. Sahin K, Onderci M, Tuzcu M, Ustundag B, Cikim G, Ozercan IH, et al. Effect of chromium on carbohydrate and lipid metabolism in a rat model of type 2 diabetes mellitus: the fat-fed, streptozotocin-treated rat. Metabolism. 2007; 5(9): 1233-1240. DOI: 10.1016/j.metabol.2007.04.021

24. Clodfelder BJ, Gullick BM, Lukaski HC, Neggers Y, Vincent JB. Oral administration of the biomimetic $[\mathrm{Cr} 3 \mathrm{O}(\mathrm{O} 2 \mathrm{CCH} 2 \mathrm{CH} 3) 6(\mathrm{H} 2 \mathrm{O}) 3]+$ 
increases insulin sensitivity and improves blood plasma variables in healthy and type 2 diabetic rats. J Biol Inorg Chem. 2005; 10(2): 119-30. DOI: $10.1007 / \mathrm{s} 00775-004-0618-0$

25. Otag A, Hazar M, Otag I, Gürkan A, Okan I. Responses of trace elements to aerobic maximal exercise in elite sportsmen. Glob J Health Sci. 2014; 6(3): 90-96. doi: 10.5539/gjhs.v6n3p90

26. Racek J, Sindberg CD, Moesgaard S, Mainz J, Fabry J, Müller L, et al. Effect of chromium-enriched yeast on fasting plasma glucose, glycated haemoglobin and serum lipid levels in patients with type 2 diabetes mellitus treated with insulin. Biol Trace Elem Res. 201; 155(1): 1-4. doi: 10.1007/s12011-013-9758-9

27. Yin RV, Phung OJ. Effect of chromium supplementation on glycated hemoglobin and fasting plasma glucose in patients with diabetes mellitus. Nutr J. 2015; 14: 14. doi: 10.1186/1475-2891-14-14

28. Ghosh D, Bhattacharyaa B, Mukherjee B, Manna B, Sinha M, Chowdhury J, et al. Role of chromium supplementation in Indians with type 2 diabetes mellitus. J Nutr Biochem. 2002; 13(11): 690-697.

29. Kleefstra N, Houweling ST, Jansman FG, Groenier KH, Gans RO, Meyboom-de Jong B, et al. Chromium treatment has no effect in patients with poorly controlled, insulin-treated type 2 diabetes in an obese Western population: a randomized, double-blind, placebocontrolled trial. Diabetes Care. 2006; 29(3): 521-525.

30. Chaudhary S, Van Horn JD. Breakdown kinetics of the trichromium(III) oxo acetate cluster $([\mathrm{Cr} 3 \mathrm{O}(\mathrm{OAc}) 6]+)$ with some ligands of biological interest. J Inorg Biochem. 2007; 101(2): 329-335. DOI: 10.1016/j.jinorgbio.2006.10.006

31. Vincent JB. Quest for the molecular mechanism of chromium action and its relationship to diabetes. Nutr Rev. 2000; 58(3 Pt 1): 67-72. DOI: 10.1111/j.1753-4887.2000.tb01841.x

32. Pechova A, Pavlata L. Chromium as an essential nutrient: A review. Vet Med (Praha). 2007; 52(1): 1-18.

33. Hamilton EM, Young SD, Bailey EH, Watts MJ. Chromium speciation in foodstuffs: A review. Food Chem. 2018; 250(1): 105-112. doi: 10.1016/j. foodchem.2018.01.016

34. Eastmond DA, Macgregor JT, Slesinski RS. Trivalent chromium: assessing the genotoxic risk of an essential trace element and widely used human and animal nutritional supplement. Crit Rev Toxicol. 2008; 38(3): 173-90. doi: 10.1080/10408440701845401

35 . Wierzejska R. Dietary supplements - panacea to contemporary health problems, or the triumph of advertisement? Med Rodz. 2017; 20(2): 136-142.

36. Song R, Mor G, Naftolin F, McPherson RA, Song J, Zhang Z, et al. Effect of Long-Term Estrogen Deprivation on Apoptotic Responses on Breast Cancer to 17 $\beta$-Estradiol. J Natl Cancer Inst. 2001; 93(22): 1714-1723.

37. Jafari F, Jafari S, Etesamnia P. Genotoxicity, Bioactivity and Clinical Properties of Calcium Silicate Based Sealers: A Literature Review. Iran Endod J. 2017; 12(4): 407-413. doi: 10.22037/iej.v12i4.17623

38. Vyšín L, Pachnerová Brabcová K, Štěpán V, Moretto-Capelle P, Bugler $\mathrm{B}$, Legube $\mathrm{G}$, et al. Proton-induced direct and indirect damage of plasmid DNA. Radiat Environ Biophys. 2015; 54(3): 343-352. DOI: 10.1007/s00411-015-0605-6

39. Chatterjee N, Walker GC. Mechanisms of DNA damage, repair and mutagenesis. Environ Mol Mutagen. 2017; 58(5): 235-263. doi: 10.1002/ em. 22087

40. Evans MD, Dizdaroglu M, Cooke MS. Oxidative DNA damage and disease: induction, repair and significance. Mutat Res. 2004; 567(1): 1-61. DOI: 10.1016/j.mrrev.2003.11.001

41. Lan J, Gou N, Gao C, He M, Gu AZ. Comparative and mechanistic genotoxicity assessment of nanomaterials via a quantitative toxicogenomics approach across multiple species. Environ Sci Technol. 2014; 48(21): 12937-12945. doi: 10.1021/es503065q

42. Eki T. Yeast-based genotoxicity tests for assessing DNA alterations and DNA stress responses: a 40-year overview. Appl Microbiol Biotechnol. 2018; 102(6): 2493-2507. DOI: 10.1007/s00253-018-8783-1

43. Czubaszek M, Szostek M, Wójcik E, Andraszek K. Test kometowy jako metoda identyfikacji niestabilności chromosomów. Postepy Hig Med Dosw. 2014; 68: 695-700.

44. Kamath GH, Rao KS. Genotoxicity guidelines recommended by International Conference of Harmonization ( $\mathrm{ICH})$. Methods Mol Biol. 2013; 1044: 431-58. doi: 10.1007/978-1-62703-529-3_24

45. Holton NW, Ebenstein Y, Gassman NR. Broad spectrum detection of DNA damage by Repair Assisted Damage Detection (RADD). DNA Repair (Amst). 2018; 66-67: 42-49. doi: 10.1016/j.dnarep.2018.04.007

46. Sobol Z, Schiestl RH. Intracellular and extracellular factors influencing $\mathrm{Cr}(\mathrm{VI})$ and $\mathrm{Cr}(\mathrm{III})$ genotoxicity. Environ Mol Mutagen. 2012; 53(2): 94-100. doi: 10.1002/em.20679
47. Zhang Q, Song Y, Amor K, Huang WE, Porcelli D, Thompson I. Monitoring $\mathrm{Cr}$ toxicity and remediation processes - combining a whole-cell bioreporter and Cr isotope techniques. Water Res. 2019; 153: 295-303. doi: 10.1016/j.watres.2019.01.009

48. Jiang B, Zhu D, Song Y, Zhang D, Liu Z, Zhang X, et al. Use of a wholecell bioreporter, Acinetobacter baylyi, to estimate the genotoxicity and bioavailability of chromium(VI)-contaminated soils. Biotechnol Lett. 2015; 37(2): 343-8. doi: 10.1007/s10529-014-1674-3

49. Zhang Q, Amor K, Galer SJG, Thompson I, Porcelli D. Using stable isotope fractionation factors to identify $\mathrm{Cr}(\mathrm{VI})$ reduction pathways: Metal-mineral-microbe interactions. Water Res. 2019; 151: 98-109. doi: 10.1016/j.watres.2018.11.088

50. Headlam HA, Lay PA. Spectroscopic characterization of genotoxic chromium (V) peptide complexes: Oxidation of Chromium (III) triglycine, tetraglycine and pentaglycine complexes. J Inorg Biochem. 2016; 162: 227-237. doi: 10.1016/j.jinorgbio.2016.06.015

51. Stearns DM, Silveira SM, Wolf KK, Luke AM. Chromium (III) tris(picolinate) is mutagenic at the hypoxanthine (guanine) phosphoribosyltransferase gene in Chinese hamster ovary cells. Mutat Res. 2002; 513(1-2): 135-142.

52. Król E, Krejpcio Z. Poglądy na temat roli chromu (III) w zapobieganiu i leczeniu cukrzycy. Diabet Prakt. 2008; 9: 168-175.

53. Stout MD, Nyska A, Collins BJ, Witt KL, Kissling GE, Malarkey $\mathrm{DE}$, et al. Chronic toxicity and carcinogenicity studies of chromium picolinate monohydrate administered in feed to F344/N rats and B6C3F1 mice for 2 years. Food Chem Toxicol. 2009; 47(4): 729-33. doi: 10.1016/j.fct.2009.01.006

54. Wang L, Wise JTF, Zhang Z, Shi X. Progress and prospects of reactive oxygen species in metal carcinogenesis. Curr Pharmacol Rep. 2016; 2(4): 178-186. doi: 10.1007/s40495-016-0061-2

55. Bock M, Schmidt A, Bruckner T, Diepgen TL. Occupational skin disease in the construction industry. Br J Dermatol. 2003; 149(6): 1165-71.

56. Wakeman TP, Yang A, Dalal NS, Boohaker RJ, Zeng Q, Ding Q, et al. DNA mismatch repair protein Mlh1 is required for tetravalent chromium intermediate-induced DNA damage. Oncotarget. 2017; 8(48): 83975-83985. doi: 10.18632/oncotarget.20150

57. Trzeciak A, Kowalik J, Małecka-Panas E, Drzewoski J, Wojewódzka M, Iwaneńko T, et al. Genotoxicity of chromium in human gastric mucosa cells and peripheral blood lymphocytes evaluated by the single cell gel electrophoresis (comet assay). Med Sci Monit. 2000; 6(1): 24-9.

58. Zhitkovich A. Chromium in drinking water: sources, metabolism, and cancer risks. Chem Res Toxicol. 2011; 24(10): 1617-29. doi: 10.1021/ tx200251t

59. Chaudhary S, Pinkston J, Rabile MM, Van Horn JD. Unusual reactivity in a commercial chromium supplement compared to baseline DNA cleavage with synthetic chromium complexes. J Inorg Biochem. 2005; 99(3): 787-94. DOI: 10.1016/j.jinorgbio.2004.12.009

60. Nguyen A, Mulyani I, Levina A, Lay PA. Reactivity of chromium(III) nutritional supplements in biological media: an X-ray absorption spectroscopic study. Inorg Chem. 2008; 47(10): 4299-309. doi: 10.1021/ ic7024389

61. Kumar D, Gangwar SP. Role of antioxidants in detoxification of Cr(VI) toxicity in laboratory rats. J Environ Sci Eng. 2012; 54(3): 441-446.

62. Rembacz KP, Sawicka E, Długosz A. Role of estradiol in chromiuminduced oxidative stress. Acta Pol Pharm. 2012; 69(6): 1372-1379.

63. Wang Y, Su H, Gu Y, Song X, Zhao J. Carcinogenicity of chromium and chemoprevention: a brief update. Onco Targets Ther. 2017; 10: 4065-4079. doi: 10.2147/OTT.S139262

64. Henkler F, Brinkmann J, Luch A. The Role of Oxidative Stress in Carcinogenesis Induced by Metals and Xenobiotics. Cancers (Basel). 2010; 2(2): 376-396. doi: 10.3390/cancers2020376

65. Jannetto PJ, Antholine WE, Myers CR. Cytochrome b(5) plays a key role in human microsomal chromium (VI) reduction. Toxicology. 2001; 159(3): 119-133.

66. Gaddameedi RR, Burgula S, Sairam M, Singh SS. Role of insulin in $\mathrm{Cr}(\mathrm{VI})$-mediated genotoxicity in Neurospora crassa. Lett Appl Microbiol. 2011; 53(1): 14-21. doi: 10.1111/j.1472-765X.2011.03058.x

67. O’Brien TJ, Jiang G, Chun G, Mandel HG, Westphal CS, Kahen K, et al. Incision of trivalent chromium [Cr(III)]-induced DNA damage by Bacillus caldotenax UvrABC endonuclease. Mutat Res. 2006; 610(1-2): 85-92. DOI: 10.1016/j.mrgentox.2006.06.015

68. Morse JL, Luczak MW, Zhitkovich A. Chromium(VI) causes interstrand DNA cross-linking in vitro but shows no hypersensitivity in cross-link repair-deficient human cells. Chem Res Toxicol. 2013; 26(10): 1591-8. doi: $10.1021 / \mathrm{tx} 400293 \mathrm{~s}$

69. Ding M, Shi X. Molecular mechanisms of Cr(VI)-induced carcinogenesis. Mol Cell Biochem. 2002; 234-235(1-2): 293-300. 
70. Figgitt M, Newson R, Leslie IJ, Fisher J, Ingham E, Case CP. The genotoxicity of physiological concentrations of chromium (Cr(III) and $\mathrm{Cr}(\mathrm{VI}))$ and cobalt $(\mathrm{Co}(\mathrm{II}))$ : an in vitro study. Mutat Res. 2010; 688(1-2):53-61. doi: 10.1016/j.mrfmmm.2010.03.008

71. El-Yamani N, Zúñiga L, Stoyanova E, Creus A, Marcos R. Chromiuminduced genotoxicity and interference in human lymphoblastoid cell (TK6) repair processes. J Toxicol Environ Health A. 2011; 74(15-16): 1030-9. doi: 10.1080/15287394.2011.582282

72. Novotnik B, Ščančar J, Milačič R, Filipič M, Žegura B. Cytotoxic and genotoxic potential of $\mathrm{Cr}$ (VI), $\mathrm{Cr}$ (III)-nitrate and $\mathrm{Cr}$ (III)-EDTA complex in human hepatoma (HepG2) cells. Chemosphere. 2016; 154: 124-131. doi: 10.1016/j.chemosphere.2016.03.118

73. NTP toxicology and carcinogenesis studies of chromium picolinate monohydrate (CAS No. 27882-76-4) in F344/N rats and B6C3F1 mice (feed studies). Natl Toxicol Program Tech Rep Ser. 2010; 556: 1-194.

74. Staniek H, Kostrzewska-Poczekaj M, Arndt M, Szyfter K, Krejpcio Z. Genotoxicity assessment of chromium(III) propionate complex in the rat model using the comet assay. Food Chem Toxicol. 2010; 48(1): 89-92. doi: 10.1016/j.fct.2009.09.020

75. Ateeq M, Rehman Ur H, Zareen S, Rehman A, Ullah W, Shah M, et al. Occupational risk assessment of oxidative stress and DNA damage in tannery workers exposed to Chromium in Pakistan. J Entomol Zool Stud. 2016; 4(6): 426-432.

76. IARC Monographs on the evaluation of carcinogenic risks to humans. Chromium, Nickiel and Welding. Vol. 49. Chromium and chromium compounds. Lyon, p. 49-256.

77. Chen QY, Murphy A, Sun H, Costa M. Molecular and epigenetic mechanisms of $\mathrm{Cr}(\mathrm{VI})$-induced carcinogenesis. Toxicol Appl Pharmacol. 2019; 377: 114636. doi: 10.1016/j.taap.2019.114636

78. Scientific Committee on Occupational Exposure Limits (SCOEL). Recommendation from the risk assessment for hexavalent chromium. 2004; SCOEL/ SUM/86

79. Toxicological profile for Chromium. Agency for Toxic Substances and Disease Registry (ATSDR). U.S. Department of Health and Human Services, Public Health Service. Atlanta 2012.

80. DeLoughery Z, Luczak MW, Zhitkovich A. Monitoring Crintermediates and reactive oxygen species with fluorescent probes during chromate reduction. Chem Res Toxicol. 2014; 27(5): 843-51. doi: 10.1021/ tx500028x

81. Macfie A, Hagan E, Zhitkovich A. Mechanism of DNA-protein crosslinking by chromium. Chem Res Toxicol. 2010; 23(2): 341-7. doi: $10.1021 /$ tx9003402

82. O’Brien TJ, Mandel HG, Sugden KD, Komarov AM, Patierno SR. Hypoxia impedes the formation of chromium DNA-adducts in a cellfree system. Biochem Pharmacol. 2005; 70(12): 1814-22. DOI: 10.1016/j. bcp.2005.09.016

83. Quievryn G, Peterson E, Messer J, Zhitkovich A. Genotoxicity and mutagenicity of chromium(VI)/ascorbate-generated DNA adducts in human and bacterial cells. Biochemistry. 2003; 42(4): 1062-70. DOI: 10.1021/bi0271547

84. Qin Q, Xie H, Wise SS, Browning CL, Thompson KN, Holmes AL, et al. Homologous Recombination Repair Signaling in Chemical Carcinogenesis: Prolonged Particulate Hexavallent Chromoium Exposure Suppresses the Rad51 Response in Human Lung Cells. Toxicol Sci. 2014; 142(1): 117-25. doi: 10.1093/toxsci/kful75

85. Cavallo D, Ursini CL, Fresegna AM, Ciervo A, Maiello R, Rondinone B, et al. Direct-oxidative DNA damage and apoptosis induction in different human respiratory cells exposed to low concentrations of sodium chromate. J Appl Toxicol. 2010; 30(3): 218-225. doi: 10.1002/jat.1487

86. Xie H, Wise SS, Holmes AL, Xu B, Wakeman TP, Pelsue SC, et al. Carcinogenic lead chomate induces DNA double-strand breaks in human lung cells. Mutat Res. 2005; 586(2): 160-172. doi: 10.1016/j. mrgentox.2005.06.002

87. Krawic C, Zhitkovich A. Toxicological Antagonism among Welding Fume Metals: Inactivation of Soluble Cr(VI) by Iron. Chem Res Toxicol. 2018; 31(11): 1172-1184. doi: 10.1021/acs.chemrestox.8b00182

88. Deng Y, Wang M, Tian T, et al. The Effect of Hexavalent Chromium on the Incidence and Mortality of Human Cancers: A Meta-Analysis Based on Published Epidemiological Cohort Studies. Front Oncol. 2019; 9: 24. doi: 10.3389/fonc. 2019.00024

89. McCarroll N, Keshava N, Chen J, Akerman G, Kligerman A, Rinde E. An evaluation of the mode of action framework for mutagenic carcinogens case study II: chromium (VI). Environ Mol Mutagen. 2010; 51(2): 89-111. doi: 10.1002/em.20525 